\title{
抗不整脈薬の薬理遺伝学的情報に基づく効果的な治療薬物モニタリング
}

\author{
土岐浩介
}

\section{Use of Pharmacogenetic Information for Therapeutic Drug Monitoring of an Antiarrhythmic Drug}

\author{
Kosuke Doki \\ Department of Pharmaceutical Sciences, Faculty of Medicine, University of \\ Tsukuba; 1-1-1 Tennodai, Tsukuba, Ibaraki 305-8575, Japan.
}

(Received May 23, 2018)

\begin{abstract}
Antiarrhythmic drugs require therapeutic drug monitoring (TDM) to avoid adverse effects such as proarrhythmia. However, TDM is not necessarily used to adjust the dosage of antiarrhythmic drugs because there is a lack of information regarding the therapeutic range of the serum concentration and the selection of patients who require TDM. The aim of this review was to provide an overview of the pharmacogenetic information on the pharmacokinetics and drug response of flecainide, a class Ic antiarrhythmic drug with a sodium channel-blocking effect. A population pharmacokinetic analysis revealed that the $C Y P 2 D 6$ genotype was a determining factor of the age-related decline in flecainide clearance. Elderly patients show large interindividual variability of flecainide clearance because they have a more pronounced effect of the CYP2D6 genotype and require more frequent monitoring of serum flecainide concentrations. Carriers of an Asian-specific promoter haplotype B of the cardiac sodium channel gene ( $S C N 5 A)$ more frequently achieve clinically relevant flecainide efficacy even at lower concentrations. This suggests that the therapeutic range of serum flecainide concentrations is lower in SCN5A promoter haplotype B carriers than in the wild-type haplotype A homozygotes. The $\beta 1$ adrenergic receptor Gly389 polymorphism decreases the antiarrhythmic efficacy of flecainide when co-administered with $\beta$-blockers. Carriers of Gly389 with co-administration of $\beta$-blockers may not achieve clinically relevant flecainide efficacy even when the serum flecainide concentrations are within the therapeutic range. These findings provide pharmacogenetic information for the effective utilization of TDM in antiarrhythmic drug therapy.
\end{abstract}

Key words — antiarrhythmic drug; therapeutic drug monitoring; pharmacogenetics; flecainide; CYP2D6 genotype; SCN5A promoter haplotype

\section{1. はじめに}

抗不整脈薬は，強力な薬理作用を有している一方 で，催不整脈作用の生じる可能性があり，安全性の 確保のために治療薬物モニタリング（therapeutic drug monitoring; TDM）を必要とする薬剤であ る. 1) 抗不整脈薬の多くは診療報酬における特定薬 剂治療管理料 1 を算定可能な TDM 対象薬である が，臨床において TDM を十分に活用できていない 現状がある。TDM を活用できていない原因として は，血中薬物濃度を医療現場で簡易に測定可能な方 法（測定キットが市販されている免疫学的測定法な

筑波大学医学医療系臨床薬剤学（干305-8575 茨城県つ くば市天王台 1-1-1)

e-mail: k-doki@md.tsukuba.ac.jp

本総説は, 平成 29 年度日本薬学会関東支部奨励賞の受

賞を記念して記述したものである.
ど）がないことや，一部の副作用の評価に心電図検 査を利用できることが挙げられる。 さらに，抗不整 脈薬の TDM を効果的に実施するために必要な情報 の不足も原因として挙げられ，特に TDM の必要性 が高い患者の識別や血中薬物濃度の有効治療域に関 する情報が十分でない。これらの情報にはそれぞれ 抗不整脈薬の体内動態及び作用発現の個人差を考慮 する必要があると考えられるが，それらの個人差と 薬理遺伝学的要因の関連は明らかにされていなかつ た.

本稿では，抗不整脈薬フレカイニドの TDM を効 果的に実施するための情報として, 筆者らが薬理遺 伝学研究に基づいて明らかにした TDM の必要性が 高い患者の識別及び有効治療域に関する薬理遺伝学 的情報について概説する. 


\section{Drug target}

Influencing factors:

e.g., $\mathrm{Na}^{+}$channel activity

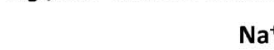

Flecainide

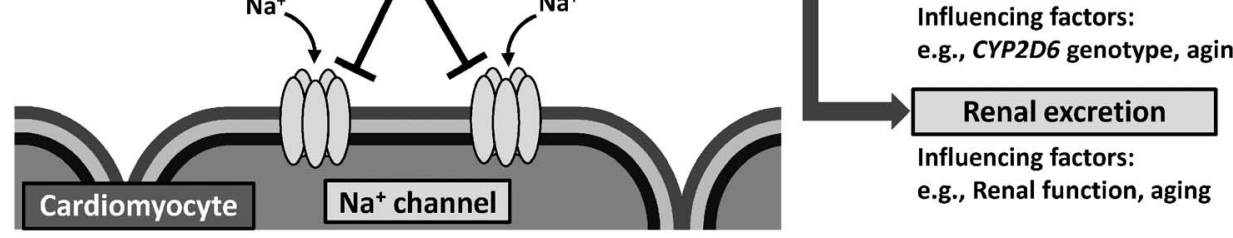

Pharmacokinetics

Hepatic metabolism

Influencing factors:

D6 genotype, aging

tion, aging

Fig. 1. Factors Influencing the Drug Target and Pharmacokinetics of Flecainide Flecainide blocks cardiac sodium channels, and undergoes hepatic metabolism and renal excretion.

\section{2. 抗不整脈薬フレカイニドの TDM}

フレカイニドは $\mathrm{Na}$ チャネル遮断作用を有する Vaughan Williams 分類 Ic 群の抗不整脈薬である. 心筋梗塞後の心室性期外収縮を抗不整脈薬で抑制す ると突然死の発生率が低下するという仮説を検証し た大規模臨床試験（Cardiac Arrhythmia Suppression Trial; CAST) においてフレカイニドが実薬と して用いられ，プラセボと比較して心臓死（特に不 整脈死）が多かつたため，その有用性が疑問視され た. ${ }^{2)}$ その後の臨床試験結果から, 心筋梗塞のよう な器質的な心疾患を有さない患者の上室性不整脈に フレカイニドを用いた場合には，CAST で示された ような心臓死のリスクが低いことが明らかになり， 現在は主に心房細動などの上室性不整脈に対して用 いられている. ${ }^{3,4)}$ 一方で, 血中フレカイニド濃度の 上昇に伴って心血管系副作用の発現リスクが増加す ることが知られており, ${ }^{5}$ 血中フレカイニド濃度を 有効治療域内に維持して治療することが重要であ る。しかし，フレカイニドは血中濃度の個人差が大 きく, $\left.{ }^{6}\right)$ 常用量であっても血中濃度が副作用域まで 上昇する患者が存在するため, ${ }^{5)} \mathrm{TDM}$ による適切 な投与量の設定が必要とされる。フレカイニドは肝 代謝（60\%）と腎排泄（40\%）により体内から消失 するため, これらの経路からの消失の変動が血中フ レカイニド濃度の個人差の原因となることが知られ ている（Fig. 1). ${ }^{7,8)}$ 血中フレカイニド濃度の有効治 療域に関してはいくつかの報告があるが, 現在用い られている上室性不整脈の抑制ではなく，CAST で 否定された心室性期外収縮の抑制を指標として多く の臨床試験において検討されていた. 8 ,9) 海外の報告 では心室性期外収縮を $90 \%$ 以上抑制できる有効血 中濃度が 200-1000 ng/mL（平均 $500 \mathrm{ng} / \mathrm{mL}$ ) であ り，わが国の報告では $200 \mathrm{ng} / \mathrm{mL}$ 以上で心室性期
外収縮の抑制効果が現れて $400 \mathrm{ng} / \mathrm{mL}$ 以上で確実 な効果が期待できるとされている. 治療域の下限は明確でなく，フレカイニドの TDM においては有効治療域の個人差も考慮する必要があ る.

3. 血中フレカイニド濃度におよばす CYP2D6 遺伝子多型の影響

フレカイニドは肝代謝及び腎排泄によって体内か ら消失するため, それらの消失経路に影響する腎機 能や年齢, 性別, 主代謝䤉素 CYP2D6 の遺伝子多 型などが血中フレカイニド濃度の変動要因となる (Fig. 1). ${ }^{10)}$ 筆者は, 血中フレカイニド濃度の個人 差におよぼすこれらの変動要因の影響を定量的に解 析して明らかにすれば，その情報を用いてフレカイ ニドの TDM が特に必要な患者を識別できると考え た。そこで，フレカイニドを服用している上室性不 整脈の患者を対象として，TDM デー夕を用いた母 集団薬物動態解析を行い, フレカイニドの消失クリ アランスの変動要因として CYP2D6 遺伝子多型な どの影響について検討した. ${ }^{11)}$ CYP2D6 の酵素活性 は，遺伝子型によりホモ extensive metabolizers [homozygous (Hom) -EMs], ヘテロ EMs [heterozygous (Het) -EMs ] 及び intermediate and poor metabolizers（IMs/PMs）に分類した。母集団薬物 動態解析の結果, 推算糸球体濾過率, 年齢, 体重及 び性別が，フレカイニドの消失クリアランスに影響 する因子であった．CYP2D6 遺伝子多型は加齢に 伴う代謝クリアランスの低下に影響しており, CYP2D6 酵素活性が低い遺伝子型（Het-EMs 及び IMs/PMs）の高齢患者では代謝クリアランスの低 下が顕著に現れていた（それぞれ $22.1 \%$ 及び $49.5 \%$ の低下）（Fig. 2)。その結果として，高齢者では若 壮年者と比較して CYP2D6 遺伝子多型の影響が顕 
A

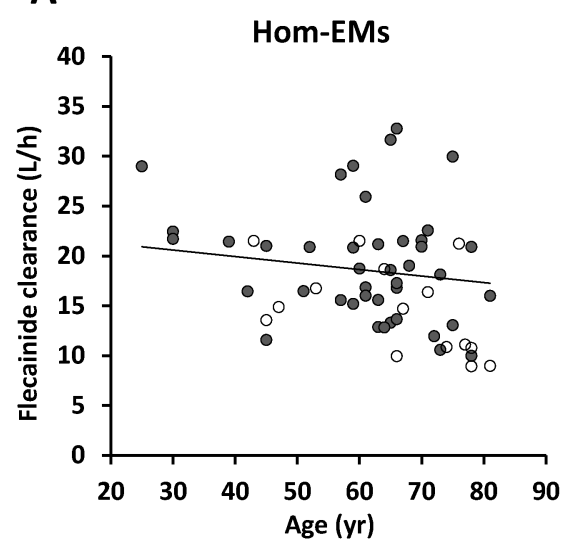

B

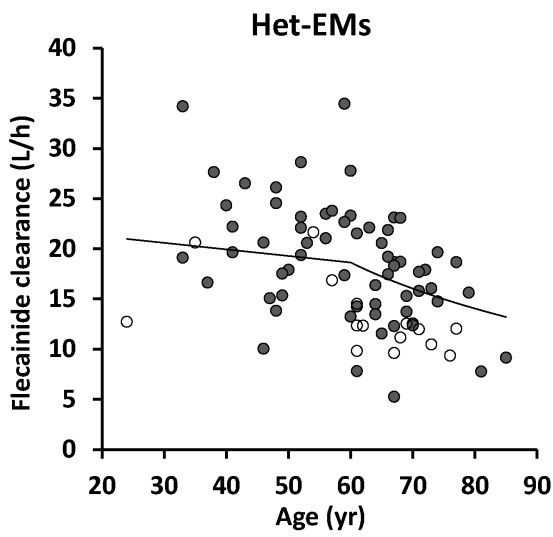

C

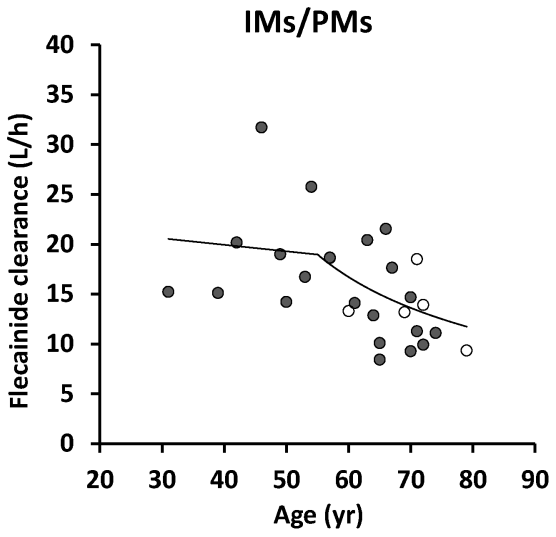

Fig. 2. Relationships between Age and Oral Flecainide Clearance for CYP2D6 Homozygous Extensive Metabolizers (Hom-EMs)

(A) , Heterozygous Extensive Metabolizers (Het-EMs) (B), and Intermediate Metabolizers and Poor Metabolizers (IMs/PMs) (C)

Solid and open circles represent male and female patients, respectively. The solid lines show the age-related decline of oral flecainide clearance predicted in the final model for a typical male patient with an average body weight. Reproduced from Ref. 11).
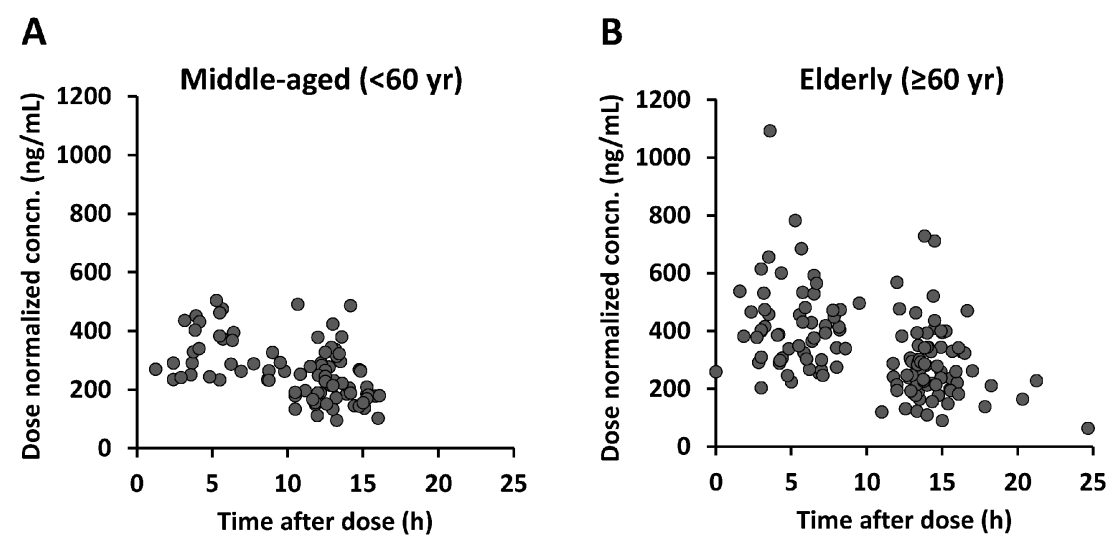

Fig. 3. Dose-normalized Serum Flecainide Concentration versus Time after Dose in Middle-aged $(<60$ yr; A) and Elderly $(\geq 60$ yr; B) Patients

著に現れるため, 血中フレカイニド濃度の個人差が 大きいことが明らかになった（Fig. 3)。よって， フレカイニドを服用している高齢者は，TDMによ る投与量の個別適正化の必要性が高いと考えられた。

4. 血中フレカイニド濃度の有効治療域におよぼ すSCN5A プロモーターのハプロタイプの影響

フレカイニドが主に用いられている上室性不整脈 において血中フレカイニド濃度の有効治療域が明ら かにされていなかつたため，筆者らは上室性不整脈 の患者における血中フレカイニド濃度と治療効果の 関連について調査した. ${ }^{6)}$ その結果, $300 \mathrm{ng} / \mathrm{mL}$ 以 上の血中フレカイニド濃度において治療効果が高 かったが, $300 \mathrm{ng} / \mathrm{mL}$ 未満の低濃度でも有効な患 者が一部存在していた。このように上室性不整脈に おける血中フレカイニド濃度の有効治療域の下限
は，心室性不整脈と同様に個人差があると推測され たがその原因は明らかでなかった，筆者は，その一 因として心筋 $\mathrm{Na}$ チャネル機能の遺伝的な個人差に よって, 抗不整脈作用を発揮するために必要な $\mathrm{Na}$ チャネル遮断薬の有効血中濃度が患者個々人で異な るのではないかと考えた（Fig. 1).

フレカイニドの作用部位である心筋 $\mathrm{Na}$ チャネル $\alpha$ サブユニットをコードする $S C N 5 A$ 遺伝子のプロ モーター領域には 6 つの連鎖する遺伝子多型 (haplotype; Hap) が知られている.12) そのうち Hap B を有する患者では, Na チャネルの発現量が 低下し， Na チャネル遮断薬の作用（心電図におけ る PR 延長や QRS 増大）が野生型の患者より強く 現れることが指摘されている，Hap B はアジア人 に特有であり（日本人のアレル頻度 : $24 \%$ ), $\mathrm{Na}$ 


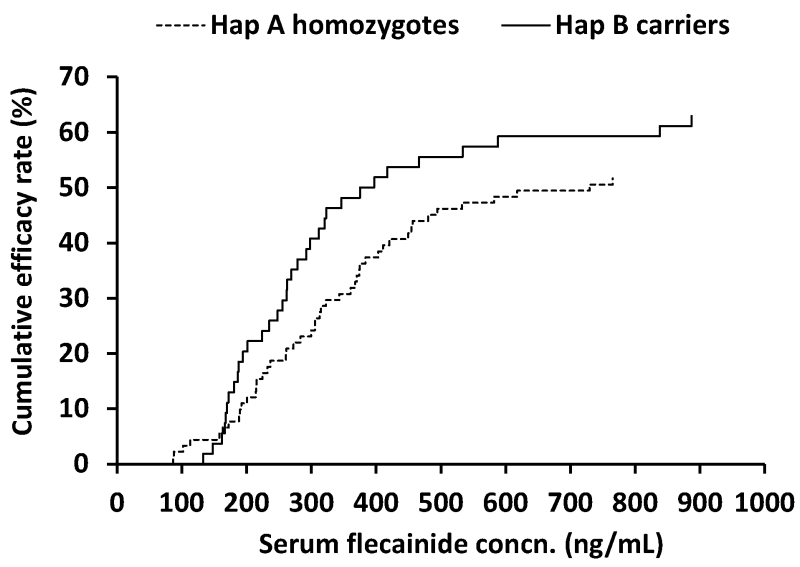

Fig. 4. Serum Concentration-cumulative Efficacy Rate Curves for the Prevention of Supraventricular Arrhythmias in Haplotype (Hap) A Homozygotes and Hap B Carriers

The cumulative efficacy rate was calculated as the percentage of patients with a positive effect accumulated up to each serum flecainide concentration in each patient group. Reproduced from Ref. 13).

チャネル遮断薬が低濃度においても有効性を示す患 者では Hap B を有している可能性があり，血中フ レカイニド濃度の有効治療域の個人差の一因となつ ている可能性が考えられた。 そこで，フレカイニド を服用している上室性不整脈の患者を対象として， $S C N 5 A$ プロモーター領域の遺伝子多型，血中フレ カイニド濃度トラフ值，及び治療効果について調査 した. ${ }^{13)}$ 野生型の Hap A のホモ（A/A） と Hap B 保有群 (A/B, B/C, B/B) の血中フレカイニド濃 度に差はなかつたが, Hap B 保有群の有効率は血 中フレカイニド濃度が $300 \mathrm{ng} / \mathrm{mL}$ 未満の患者にお
いて A/A 群より高かった (69\% vs. 43\%, Fig. 4). また， A/A 群の $300 \mathrm{ng} / \mathrm{mL}$ における累積有効率は 24\%であったが，Hap B 保有群はこの累積有効率 を $200 \mathrm{ng} / \mathrm{mL}$ 付近で得ていた。 よって, SCN5Aプ ロモーターの Hap B 保有群では $300 \mathrm{ng} / \mathrm{mL}$ 未満の 低濃度でも奏功するケースが多いと考えられた。一 方で，血中フレカイニド濃度が $300 \mathrm{ng} / \mathrm{mL}$ 以上の 患者において，Hap B 保有群では A/A 群と比較し て心電図の PR 延長と $\mathrm{QRS}$ 増大が顕著であり (Fig. 5)，フレカイニドによる刺激伝導遅延が過剩 に起こっている可能性がある.よって, Hap B 保 有群の有効治療域は $\mathrm{A} / \mathrm{A}$ 群より低濃度側にシフト している可能性があり，このことを考慮してフレカ イニドの TDM を行う必要があると考えられた。

5. フレカイニドの治療効果におよばす $\beta 1$-アド レナリン受容体 Arg389Gly 遺伝子多型の影響

$\beta 1$-アドレナリン受容体（ $\beta 1$-adrenergic receptor; $\beta 1 \mathrm{AR})$ はアデニル酸シクラーゼの活性化経路を介 して Na チャネルを抑制することが in vitro におい て示唆されている. ${ }^{14)} \beta 1 \mathrm{AR}$ には Arg389Gly 遺伝子 多型が存在し(日本人の Gly389 アレル頻度：22\%), Gly389 は Arg389 に比べてイソプレナリン刺激によ るアデニル酸シクラーゼ活性化が減弱することが in vitro において示されている. ${ }^{15)}$ Gly389 を有する 患者では $\mathrm{Na}$ チャネル遮断薬であるフレカイニドの 抗不整脈効果の低いことが報告されており，これは $\beta 1 \mathrm{AR}$ を介した Na チャネル抑制が減弱しているた

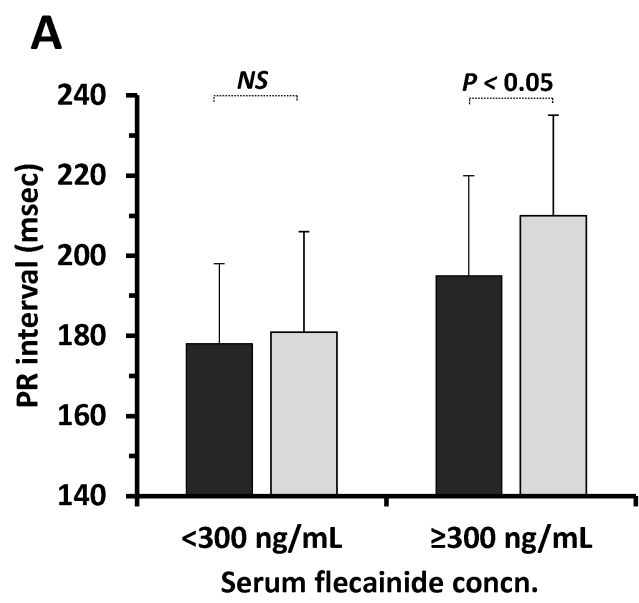

口: Hap A homozygotes

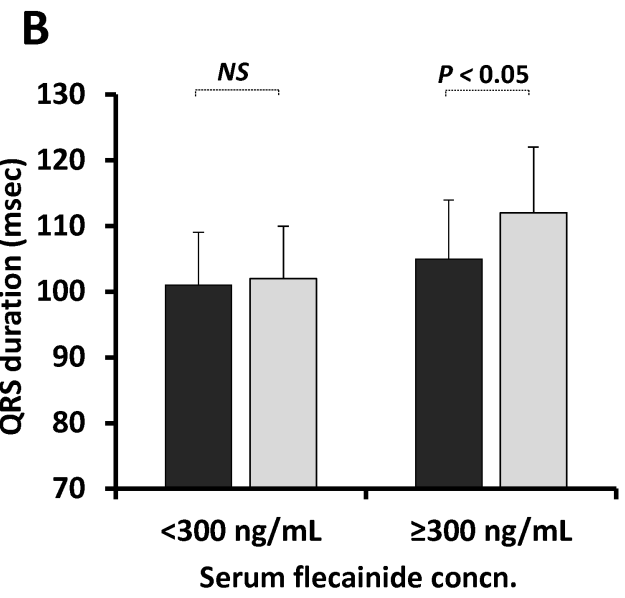

$\square:$ Hap B carriers

Fig. 5. Effects of the SCN5A Promoter Haplotype (Hap) on the ECG Data for Sinus Rhythm while under Flecainide Treatment $\mathrm{A}, \mathrm{PR}$ interval; B, QRS duration. 
A

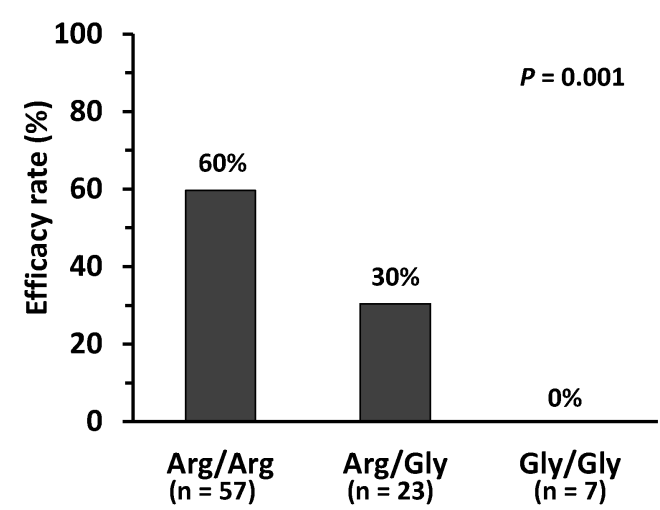

B

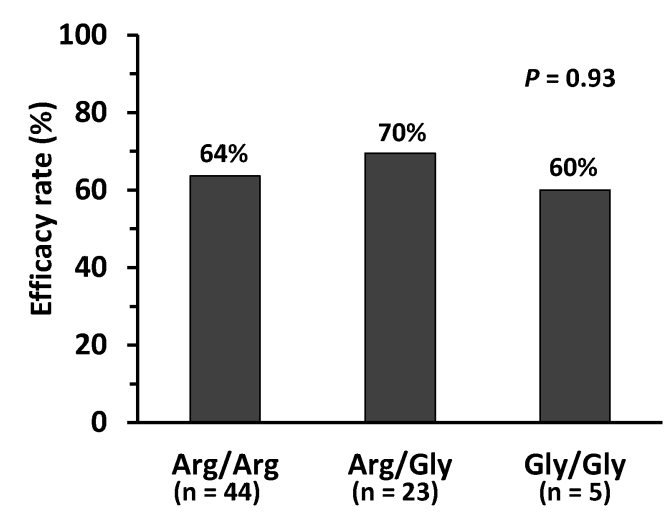

Fig. 6. Relationships between the $\beta 1$-Adrenergic Receptor Arg389Gly Polymorphism and the Antiarrhythmic Efficacy of Flecainide among Patients with Coadministration of $\beta$-Blockers (A), and Patients without Coadministration of $\beta$-Blockers (B) Arg/Arg, Arg389-homozygotes; Arg/Gly, Gly389-heterozygotes; Gly/Gly, Gly389-homozygotes. Reproduced from Ref. 17).

Table 1. Pharmacogenetic Information for the Effective Utilization of Therapeutic Drug Monitoring in Flecainide Therapy

\begin{tabular}{|c|c|c|}
\hline Genetic factors & Pharmacogenetic information & Comments \\
\hline$C Y P 2 D 6$ genotype & $\begin{array}{l}C Y P 2 D 6 \text { genotype is a determinant factor of age- } \\
\text { related decline in metabolic clearance of flecainide, } \\
\text { resulting in a more pronounced effect of the } \\
C Y P 2 D 6 \text { genotype in elderly. }\end{array}$ & $\begin{array}{l}\text { Elderly patients require a monitoring of serum } \\
\text { flecainide concentration because they show large } \\
\text { inter-individual variability of flecainide clearance. }\end{array}$ \\
\hline $\begin{array}{l}S C N 5 A \text { promoter } \\
\text { haplotype }\end{array}$ & $\begin{array}{l}\text { The therapeutic range of serum flecainide concen- } \\
\text { trations is lower in haplotype B carriers than in the } \\
\text { wild-type haplotype A homozygotes. }\end{array}$ & $\begin{array}{l}\text { Should keep in mind that some patients achieve } \\
\text { clinically relevant efficacy even at lower flecainide } \\
\text { concentrations. }\end{array}$ \\
\hline $\begin{array}{l}\beta 1 \text {-Adrenergic receptor } \\
\text { polymorphism }\end{array}$ & $\begin{array}{l}\text { The } \beta 1 \text {-adrenergic receptor Gly } 389 \text { polymorphism } \\
\text { decreases the antiarrhythmic efficacy of flecainide } \\
\text { when co-administered with } \beta \text {-blockers. }\end{array}$ & $\begin{array}{l}\text { Should consider changing medication if the patient } \\
\text { with co-administration of } \beta \text {-blockers does not } \\
\text { achieve clinically relevant efficacy even at therapeu- } \\
\text { tic flecainide concentrations. }\end{array}$ \\
\hline
\end{tabular}

めと推測されている. ${ }^{16)}$ 一方で, 本報告では 9 割の 患者が $\beta$ 受容体遮断薬を併用していたため，その 併用が Arg389Gly 遺伝子多型と関連したフレカイ ニドの治療効果に影響した可能性がある. そこで, 筆者らはフレカイニドの治療効果におよぼす $\beta 1 \mathrm{AR}$ の Arg389Gly 遺伝子多型の影響が $\beta$ 受容体遮断薬 の併用の有無によつて異なるか否かについて検討し た. ${ }^{17)}$ フレカイニドを服用している上室性不整脈の 患者を対象として， $\beta 1 \mathrm{AR} の \mathrm{Arg} 389 \mathrm{Gly}$ 遺伝子多 型と治療効果の関係について検討した。 Arg/Arg 群，Arg/Gly 群及び Gly/Gly 群の血中フレカイニ ド濃度に差はなかったが，不整脈に対する有効率は Gly389 保有患者で低下する傾向を認めた（61\%vs. $50 \%$ vs. $25 \%$ ）。この傾向は $\beta$ 受容体遮断薬を併用 している患者で顕著であり，Gly389 保有により有 効率は低下した $[60 \% v s .30 \%$ vs. 0\%, Fig. 6(A)].
一方, $\beta$ 受容体遮断薬を併用していない患者では Gly389 保有による有効率の低下は認められなかっ た [Fig. 6(B)]。 $\beta$ 遮断薬を併用している場合, Gly389 保有者では血中フレカイニド濃度が有効治 療域内であっても十分な治療効果が得られない可能 性も考慮して TDM を行う必要がある。よって, Gly389 変異保有者に対する TDM では他剤への変 更も考慮する必要があると考えられた.

\section{6. おわりに}

筆者はフレカイニドの薬理遺伝学研究の結果か ら，加齢に伴う消失 CL の低下に影響する CYP2D6 遺伝子多型, 有効治療域を低濃度にシフ 卜する SCN5A プロモーター遺伝子多型，及び $\beta$ 遮 断薬併用時に治療効果が低下する $\beta 1 \mathrm{AR}$ の遺伝子 多型がフレカイニドの TDM において重要であるこ とを明らかにした。フフカイニドの TDMによる個 
別適正化の必要性は $C Y P 2 D 6$ 遺伝子変異を有する 高齢者において高く，フレカイニドの治療効果にお ける遺伝的な個人差によって低濃度でも有効な患者 や $\beta$ 遮断薬併用時に治療効果が低下する患者が存 在することも考慮して TDM を行う必要があると考 えられる (Table 1)。今後, 他の抗不整脈薬につい ても薬理遺伝学研究が行われて, 本稿で概説した薬 理遺伝学的情報の他の抗不整脈薬への応用性が確認 されることが期待される.

謝辞本研究の遂行にあたり，御指導を賜りま した筑波大学医学医療系 本間真人教授, 筑波大学 幸田幸直名誉教授に心より感謝申し上げます。ま た，共同研究に際して，御協力と多くの御助言を賜 りました筑波大学医学医療系循環器内科 青沼和隆 教授，久賀圭祐教授，関口幸夫准教授並びに熱心に 研究に取り組んでくれた学生諸氏に御礼申し上げま す.

利益相反＼cjkstart開示すべき利益相反はない.

\section{REFERENCES}

1) Aonuma K., Shiga T., Atarashi H., Doki K., Echizen H., Hagiwara N., Hasegawa J., Hayashi H., Hirao K., Ichida F., Ikeda T., Maeda Y., Matsumoto N., Sakaeda T., Shimizu W., Sugawara M., Totsuka K., Tsuchishita Y., Ueno K., Watanabe E., Hashiguchi M., Hirata S., Kasai H., Matsumoto Y., Nogami A., Sekiguchi Y., Shinohara T., Sugiyama A., Sumitomo N., Suzuki A., Takahashi N., Yukawa E., Homma M., Horie M., Inoue H., Ito H., Miura T., Ohe T., Shinozaki K., Tanaka K., Circ. J., 81, 581612 (2017).

2) Echt D. S., Liebson P. R., Mitchell L. B., Peters R. W., Obias-Manno D., Barker A. H., Arensberg D., Baker A., Friedman L., Greene H. L., N. Engl. J. Med., 324, 781-788 (1991).

3) Pritchett E. L., Wilkinson W. E., Am. J. Cardiol., 67, 976-980 (1991).

4) Dorian P., Naccarelli G. V., Coumel P., Hohn- loser S. H., Maser M. J., Am. J. Cardiol., 77, 89A-95A (1996).

5) Salerno D. M., Granrud G., Sharkey P., Krejci J., Larson T., Erlien D., Berry D., Hodges M., Clin. Pharmacol. Ther., 40, 101107 (1986).

6) Homma M., Kuga K., Doki K., Katori K., Yamaguchi I., Sugibayashi K., Kohda Y., $J$. Pharm. Pharmacol., 57, 47-51 (2005).

7) McQuinn R. L., Quarfoth G. J., Johnson J. D., Banitt E. H., Pathre S. V., Chang S. F., Ober R. E., Conard G. J., Drug Metab. Dispos., 12, 414-420 (1984).

8) Conard G. J., Ober R. E., Am. J. Cardiol., 53, 41B-51B (1984).

9) Kanazawa T., Miura M., Sasaki W., Kadowaki K., Shu T., Homma M., Hayashi M., Sato S., Unno K., Suzuki T., Tada H., Jpn. J. Clin. Pharmacol. Ther., 21, 713-723 (1990).

10) Doki K., Homma M., Kuga K., Kusano K., Watanabe S., Yamaguchi I., Kohda Y., Eur. J. Clin. Pharmacol., 62, 919-926 (2006) .

11) Doki K., Homma M., Kuga K., Aonuma K., Kohda Y., Pharmacogenet. Genomics, 22, 777-783 (2012).

12) Bezzina C. R., Shimizu W., Yang P., Koopmann T. T., Tanck M. W., Miyamoto Y., Kamakura S., Roden D. M., Wilde A. A., Circulation, 113, 338-344 (2006) .

13) Doki K., Homma M., Kuga K., Aonuma K., Kohda Y., Pharmacogenet. Genomics, 23, 349-354 (2013).

14) Cragun K. T., Johnson S. B., Packer D. L., Circulation, 96, 2701-2708 (1997).

15) Mason D. A., Moore J. D., Green S. A., Liggett S. B., J. Biol. Chem., 274, 12670-12674 (1999)

16) Nia A. M., Caglayan E., Gassanov N., Zimmermann T., Aslan O., Hellmich M., Duru F., Erdmann E., Rosenkranz S., Er F., PLoS One, 5, e11421 (2010).

17) Doki K., Sekiguchi Y., Kuga K., Aonuma K., Homma M., Pharmacogenet. Genomics, 26, 481-485 (2016). 